\title{
P-19 EXPLORATION FOR CRUDE OIL AND NATURAL GAS IN THE WEST CARPATHIANS, SLOVAKIA
}

JULIAN ZELMAN ${ }^{1}$, MIROSLAV PERESZLENYI', ROBERT VITALOS ${ }^{1}$ and JAN MILICKA ${ }^{2}$ 'Slovak Gas Industry, VVNP, Votrubova 11/a, 82505 Bratislava, Slovak Republic ${ }^{2}$ Comenius University

\section{INTRODUCTION}

From viewpoint of world-wide petroleum occurrence the West Carpathians belong to rather average than important oil-bearing territories. However prospection, exploration and production of crude oil and natural gas, have a long-term tradition in this territory.

Recently there has been a revival of interest for oil exploration in West Carpathians of Slovakia, as a result of new petroleum-geological investigations, revaluation of older exploration works and organic-geochemical research of potential source rocks, oils, gases and solid bitumens.

\section{NEOGENE BASIN}

Young sedimentary Neogene basins of the West Carpathians (Fig.1) are filled by silicaclastic deposits (clay/claystone, silt/siltstone, gravel/conglomerate) accompanied by volcanics, coal seams, rarely by evaporites. They were deposited in marine, hyposaline, fluviolacustrine and terrestrial conditions Thickness of some basin fill reaches several $1000 \mathrm{~m}$.. The source of organic compounds of basin deposits is represented by the decay products of terrestrial, lacustrine and partly marine organic matter.

Total content of the organic matter depends on a depositional environment. The total organic carbon (TOC) content in these basins is rather poor (0.5-1.0 wgt \%) but locally also fairly good (2.0-5.0 wgt \%). After organic-geochemical investigation of cores from deep boreholes the most prospective potential source rocks are underlying Paleogene sediments of intramount Neogene depressions, Lower Miocene sediments of the Vienna Basin, Middle Miocene sediments of the East Slovakian Basin, underlying Paleogene sediments and Early Pannonian sediments of the Danube Basin. Dominant kerogen type is the terrestrial one (III, $\mathrm{HI}=100-250 \mathrm{mg} \mathrm{HC} / \mathrm{g} \mathrm{TOC}$ ), but locally, mainly in marine and lacustrine deposits also mixed marine-terrestrial type (II-III, HI=300-400 mg HC/g TOC) and type II (HI 500 mg HC/g TOC). 
Maturation depth trend in individual basins is significantly different. In the East Slovakian Basin kerogen maturation and conversion into hydrocarbons takes place in the shallowest depths, deeper in the Danube Basin and deepest in the Vienna Basin. Kerogen maturation modelling based on burial history of sediments and on geothermal conditions indicates that differences are mainly due to a different geothermal gradient. The geothermal gradient and relative rate of the kerogen alteration influenced also the range of the hydrocarbon generation windows. Depending on local geothermal conditions there are differences in organic matter maturation also in partial areas of mentioned basins. Globally, these differences are most recognisable between the northern and southern parts of basins as a result of the sedimentation area inversion.

The average hydrocarbon potential is about $0.5-2.0 \mathrm{~kg} \mathrm{HC} / \mathrm{t}$ of rock, in the best horizons 3-7 kg HC/t of rock. Depending on the thermal alteration and depth positions most of Paleogene and partly Early Miocene sediments (mainly in intramount depressions) is in relict generation stage. The active oil generation can be actually expected in the deepest Paleogene sediments, sediments of Early and partly Middle Miocene in the Vienna Basin, Middle Miocene sediments in the East Slovakian Basin and Early Pannonian sediments in the central part of the Danube Basin.

\section{OUTER CARPATHIANS}

Outer Carpathian (Flysch Belt and Klippen Belt - Fig.1) sediments have a fairly good hydrocarbon generating potential. Upper Cretaceous to Oligocene shales represent potentially rich source rocks, the best of which are Menilite shales. Present organic matter alteration suggests that a part of hydrocarbon potential was realized during geological development of the area in original sedimentary basins prior to Oligocene. After the flysch nappes overthrusting in Oligocene there was activated hydrocarbon potential of the youngest Upper Eocene to Oligocene sequences, in Slovak territory mainly Krosno-Menilite beds of Silesian and Dukla nappes. Sedimentary organic matter of the Upper Eocene to Oligocene flysch sequences was not sufficiently deeply buried to reach a distinctive alteration. These sediments entered the hydrocarbon generation stage only after deeper burial by back nappes. The occurrence of hydrocarbon accumulations is expected close to junction zones of flysch nappes.

Organic-geochemical investigation has shown that the most prospective potential source rocks are represented by Krosno-Menilite beds with TOC values up to 10 wgt \% residual hydrocarbon potential up to $50 \mathrm{mg} \mathrm{HC/g}$ rock and marine kerogen type in shales in early stage of maturation (300 - $600 \mathrm{mg} \mathrm{HC} / \mathrm{g}$ TOC). More or less, but still prospective potential source rocks were found also in shales of underlying older beds with terrestrial kerogen type. However, most 
of maturation data from cores of existing deep wells indicate high stages of maturation (top oil condensate - gas) from the surface towards depth in older Upper Cretaceous - to Middle Eocene sequences.

Sediments of the underlying West Carpathians Foreland in the area of the Flysch Belt in Slovak territory are submerged mostly into the depth more than $8 \mathrm{~km}$. In such a depth they would be probably overmatured. However, we could expect the hydrocarbons generation in the north-western territory of Slovakia, where they are situated at the depth between 3 to $8 \mathrm{~km}$ below the overthrusted Flysch Belt.

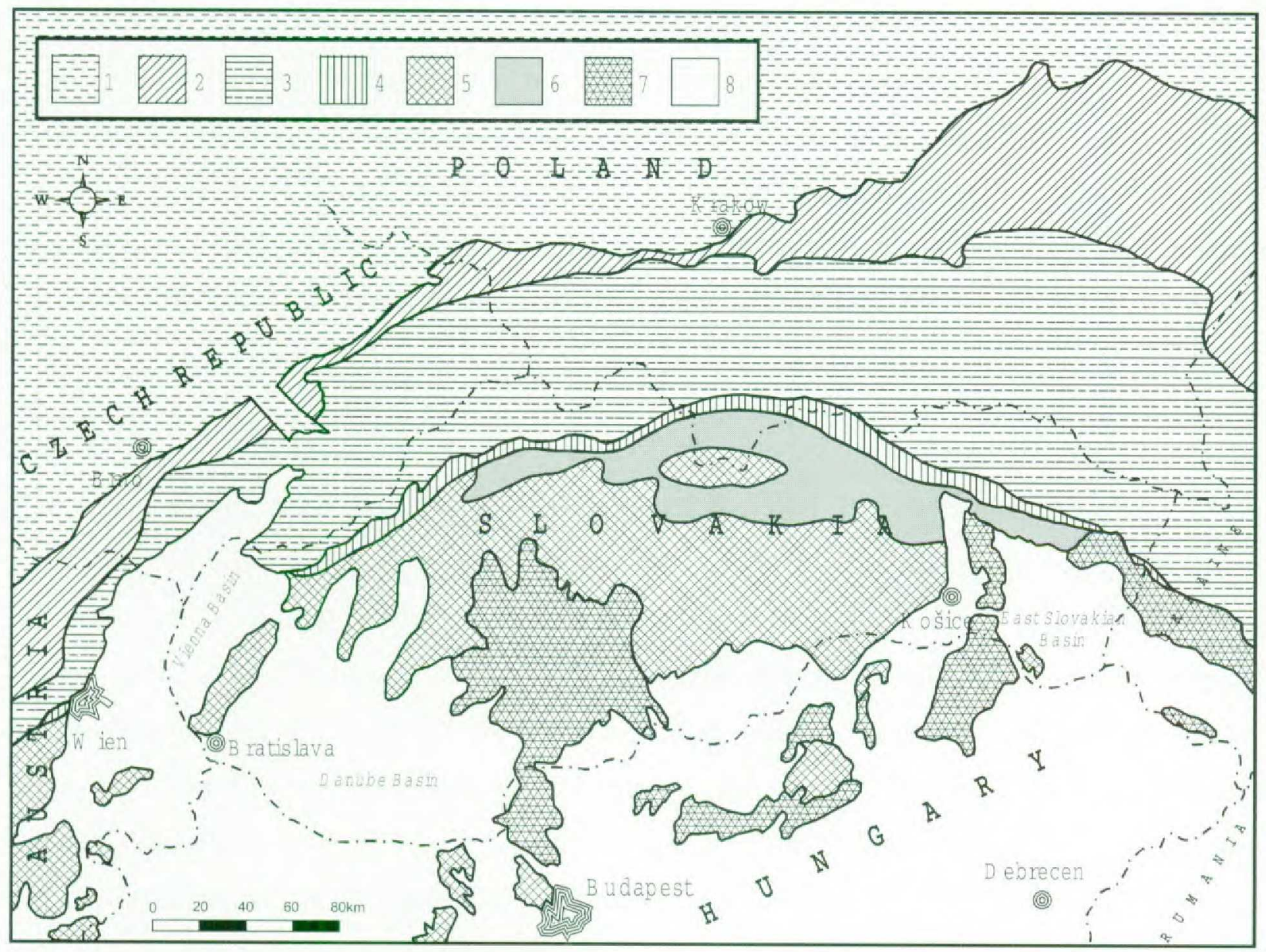

Figure. 1 Position of the W estC arpathians in C entral Europe

1 - European P latform , 2 - W estC arpathians and A Ip ine Foredeep, 3 - A lp ine - C arpathian F lysch B elt, 4 - P ieniny $K$ lippen B elt, 5 - C alc A lps - InnerW estC arpathians, 6 - C entral C arpathian Paleogene $\mathrm{B}$ asins, 7 - Late C ainozo ic Volcanic Rocks, 8 - N eogene B asins

\section{CENTRAL CARPATHIAN PALEOGENE BASINS}

Central Carpathian Paleogene basins (Fig.1) comprise subsiding areas of the destructive plate margin. The total organic carbon content of Paleogene shaly source rocks with disseminated organic matter is up to $2 \mathrm{wgt} \%$. The kerogen is predominantly terrestrial. 
However, the hydrocarbon generation potential in northern part of basing adjacent to the periKlippen Belt is exhausted to a consideráble extent.

The highest maturation level within Paleogene sediments was reached in the northern part ( $\mathrm{Ro}=0.6 \%$ in $1 \mathrm{~km}$ and $\mathrm{Ro}=1.8 \%$ in $2 \mathrm{~km}$ of depth). Present residual hydrocarbon potential is of approx. $0.19-0.80 \mathrm{~kg} \mathrm{HC} / \mathrm{t}$ and represents only a relict of the original hydrocarbon potential. This maturation stage was reached in geological past at considerably greater depth. Area with relative less matured organic matter lies more southernward. The maturation stage corresponds here to an early oil production stage with the total hydrocarbon potential of about $0.8-5.5 \mathrm{~kg}$ $\mathrm{HC} / \mathrm{t}$.

\section{INNER WEST CARPATHIANS}

Metamorphic disconformity between Tertiary to Upper Cretaceous sandy, shaly and Mesozoic-Paleozoic carbonate sequences is indicated by vitrinite reflectance (offset of approx. $0.6 \%$ ). Present depth and temperature conditions exclude pre-Upper Cretaceous sediments from being actively producing potential source rocks. Geological reconstruction indicates that present maturation stage of Mesozoic-Paleozoic sediments was reached within the period of the Middle to Late Cretaceous and was not significantly influenced by sedimentation of overlying Tertiary sequences.

\section{CONCLUSION}

Based on sedimentary organic matter maturation level it is possible to generalize, that in active maturation or hydrocarbon generation stages respectively, in West Carpathian territory occure sediments of stratigraphic range from Upper Cretaceous to Tertiary.

In conclusion it is possible to state that prospective areas of West Carpathians from viewpoint of hydrocarbon exploration are as follows:

- Deeper parts of Neogene basins, i.e. traditional areas of petroleum exploration,

- Sediments of the "Central Carpathian Paleogene" and

- Folded Flysch Belt with underlying West Carpathian Foreland.

Based on organic-geochemistry investigation there are no doubts on hydrocarbon potential of these areas, but knowledge on potential reservoir rock is poor. However, more detailed data can be expected from future seismic and drilling exploration. 